\title{
Screen Printed Sensor for Enuresis Alarm System
}

\author{
Marianna Grecka ${ }^{1}$, Aleksandrs Valisevskis ${ }^{2}$, Inese Parkova ${ }^{3}$, Ausma Vilumsone $^{4}$ \\ ${ }^{1-4}$ Riga Technical University, Institute of Textile Materials Technologies and Design
}

\begin{abstract}
The aim of the study - the development of textile screen printed sensor for enuresis alarm system, using different concentrations of graphite in paste and various width of traces (3, $5,7 \mathrm{~mm})$.

The most optimal parameters of concentration $(22 \%)$ and width $(7 \mathrm{~mm})$ of traces, which were printed on sateen weave cotton fabric, are found by measuring the resistivity and the change of voltage in time during dropping the salty dilution.

The more graphite concentration and width, the less resistivity is observed.
\end{abstract}

Keywords: graphite, screen printing, sensor, enuresis.

\section{INTRODUCTION}

Wearable electronics tend to get smaller and take over features of textile materials [17]. Smart textiles can be obtained by integrating conductive fibres and yarns, e-yarns, using conductive coatings (flexible encapsulated circuits) or conductive pastes and inks [10].

It makes it reasonable to screen-print conductive traces, circuits, antennas and sensors directly on textile substrates, using textile pastes and inks loaded with different conductive fillers $[8,10,9]$. The inks can contain: metals (gold, silver, copper, aluminum powder, flakes, fibres or nanowires), carbon (powder, nanotubes, nanofibres) and intrinsically conductive polymers (polyaniline, polypyrrole) $[1,12]$.

Most commercial conductive pastes, inks and paints for printed electronics are devised for printing/applying on plain and rigid surface. The most popular are DuPont, Sun Chemical ${ }^{\circledR}$, Creative Materials, EPO-TEK $\AA$, PELCO $\AA$, Acheson Chemical, Ecojoin, Caig Laboratories Inc., MG Chemicals etc. $[3,5,7,15,19,20]$. Despite non-textile application, a research of applying some of these pastes was carried out, evaluating the features of pastes/inks and their interaction with different structures and surfaces of textile materials $[16,14]$.

Carbon $(C)$ is the main component of plants and life creations, and it is also used in metallurgy, electrode production, adsorbing, in chemical industry etc. In nature carbon can be met as diamond (Fig. 1 a), graphite (Fig. 1 b) and charcoal (Fig. 1 g). Carbon and its allotropes (different molecular configurations) (Fig.1) tend to take stand of usage in electronics increasingly [2].

Graphite has a layered structure, as bonds among carbon atoms in a layer are tight, but bonds between layers are weak. Thereby graphite is soft, because layers of atoms can slide along each other. Graphite is nontransparent, dark grey and a good conductor [4].
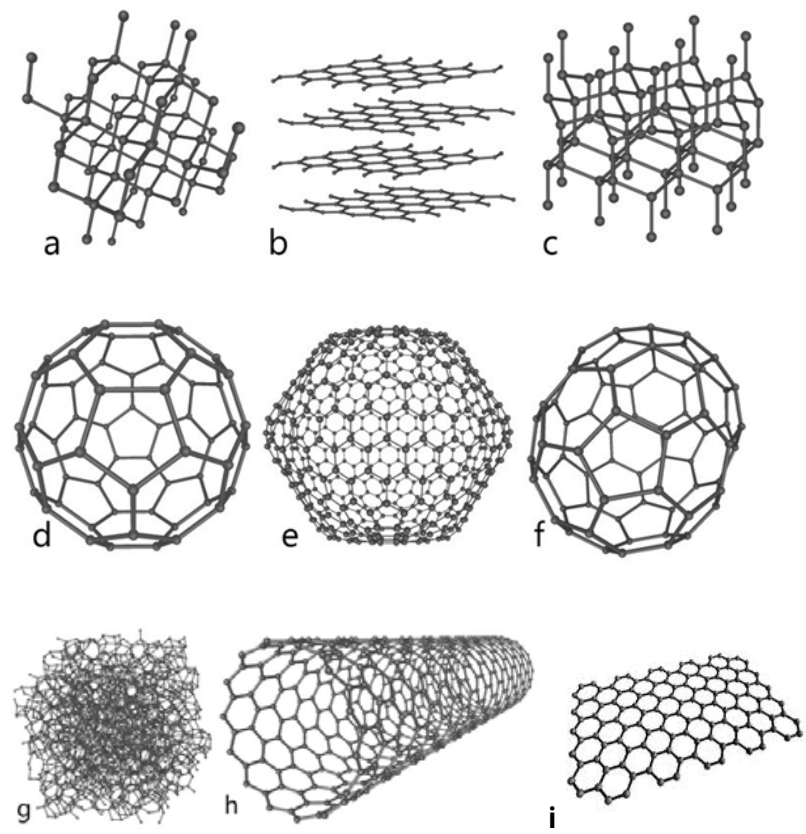

Fig. 1 The structures of allotropes of carbon: diamond (a), graphite (b), lonsdaleite (c), buckminsterfullerene (C60) (d), fullerene (C540) (e), fullerene (C70) (f), amorphous carbon (g), single-walled carbon nanotube (h), grapheme (i) $[2,6]$

Screen printed sensors made by depositing graphite-based paste on textile material can be used for nocturnal enuresis alarm systems as alternative of prototyped sensors made of conductive yarns [13]. Both methods are replacing rigid sensors and increasing the comfort of usage.

Such alarm systems can be used by individuals with diagnosis of bed-wetting or nocturnal enuresis. Enuresis is intermittent incontinence during sleep of mostly children after the age of five, caused by different disturbances of physiology. The bed-wetting alarm system awakens the child when bedwetting starts and he/she finishes voiding in the toilet [11].

The aim of the study is to develop a textile screen printed sensor for the existing [13] enuresis alarm system, using different concentrations of carbon in printing paste and printing different thickness of traces.

\section{METHODS}

\section{A. Screen printing}

The screen printed technology was used for printing traces for sensor [18]. Firstly, the pattern of $3 \mathrm{~mm}, 5 \mathrm{~mm}$ and $7 \mathrm{~mm}$ thick and $100 \mathrm{~mm}$ long traces were created digitally. Using emulsion, a picture of patterns and light, the patterns were 
transferred onto a screen (mesh), which was fixed into frame (size A4).

Different quantities of graphite powder were mixed with water based transparent textile printing paste (TPrint T2000), producing various concentrations of carbon printing pastes (Table). Using rubber squeegee and patterned screen $3 \mathrm{~mm}$, $5 \mathrm{~mm}$ and $7 \mathrm{~mm}$ wide traces were printed on sateen $\left(123,2 \mathrm{~g} / \mathrm{m}^{2}\right)$ weave cotton fabric (Fig.2). For each concentration and trace type 5 samples were printed. The samples were dried and fixed for a minute at temperature of $120^{\circ} \mathrm{C}$.

TABLE

CONCENTRATIONS OF GRAPHITE POWDER IN PASTES

\begin{tabular}{|c|c|c|c|c|}
\hline Nr. & Concentration, $\%$ & $3 \mathrm{~mm}$ & $5 \mathrm{~mm}$ & $7 \mathrm{~mm}$ \\
\hline 1. & 10 & 5 & 5 & 5 \\
\hline 2. & 14 & 5 & 5 & 5 \\
\hline 3. & 18 & 5 & 5 & 5 \\
\hline 4. & 22 & 5 & 5 & 5 \\
\hline 5. & 26 & 5 & 5 & 5 \\
\hline \multicolumn{4}{|c|}{ Total number of trace samples: } & 75 \\
\hline
\end{tabular}

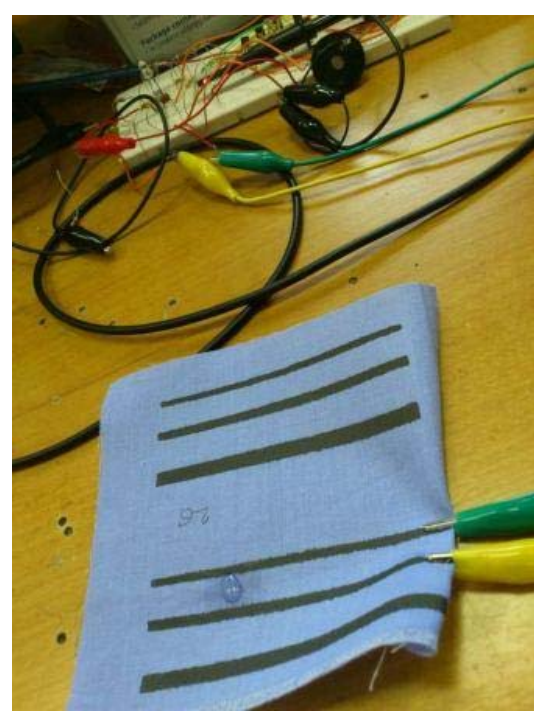

Fig. 2 Printed traces which are connected electrodes

\section{B. Testing Reaction on Humidity}

Testing the reaction on humidity salty dilution $(0,2$ moles of salt per 1 litre of water) was used for urine imitation, because its conductivity corresponds to the average conductivity of urine [21]. Salt $(\mathrm{NaCl})$ is an electrolyte, and when it is diluted in water to form salt water, it becomes sodium ions $(\mathrm{Na}+)$ and chlorine ions (Cl-), each of which is a particle that conducts electricity [13]. To register the above mentioned reaction, additionally, oscilloscope and program Pico Scope 6 were used. The electrodes were connected to two parallel printed traces through a simple signal amplifier, shown in Figure 3, which increased sensitivity of the system. In this experimental setup the electronic circuit was fed with $2 \mathrm{~V}$ input voltage, which was connected to an amplifying transistor through a sensor with printed traces (connections SENS 1 and SENS2). The reaction of the system was indicated in two ways - with LED1 and with measuring connections (MEAS1 and MEAS2), which were connected to an oscilloscope, which measured and registered the output voltage of the system. The dilution was dropped between the traces and the increase of voltage in time between two traces was registered. The traces with width of $5 \mathrm{~mm}$ and $7 \mathrm{~mm}$ and all concentrations (Table 3) of graphite powder were measured, because they have lower resistance than $3 \mathrm{~mm}$ traces.

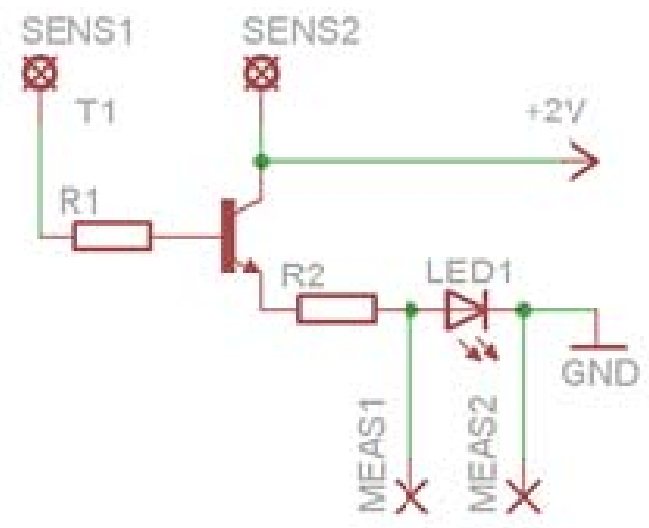

Fig. 3 Experimental set-up for sensor testing

\section{RESULTS \& DisCUSSION}

\section{A. Resistance of Printed Traces}

After the heat treatment, the resistivity of the acquired samples of printings was measured. The observed tendency shows that by increasing the concentration of graphite paste, the electrical resistivity decreases. It happens till the concentration of $22 \%$, because the resistance begins to rise at the concentration of $26 \%$. If the factors as printing mesh dimensions and size of graphite flakes remain the same, the resistivity will increase.

In previous pilot-experiments traces of the graphite paste of $50 \%$ and $60 \%$ concentration were printed on fabric. It was observed that the paste is not absorbed into textile structure and cracks appear in the printed traces, which cause more resistance. This can be explained by excessive size of graphite powder flakes for the chosen fabric and its structure. The graphite powder stays on the surface of fabric, while the textile paste is absorbed into fabric, so fabric acts like a filter.

The concentration of $10 \%$ and $14 \%$ of graphite pastes shows that the width of traces affects electrical resistance thicker traces of $7 \mathrm{~mm}$ have lower resistance than traces of $5 \mathrm{~mm}$ and $3 \mathrm{~mm}$ (Fig. 4). But resistance becomes less different with $18 \%, 22 \%$ and $26 \%$ concentration of graphite despite the various widths of traces. 


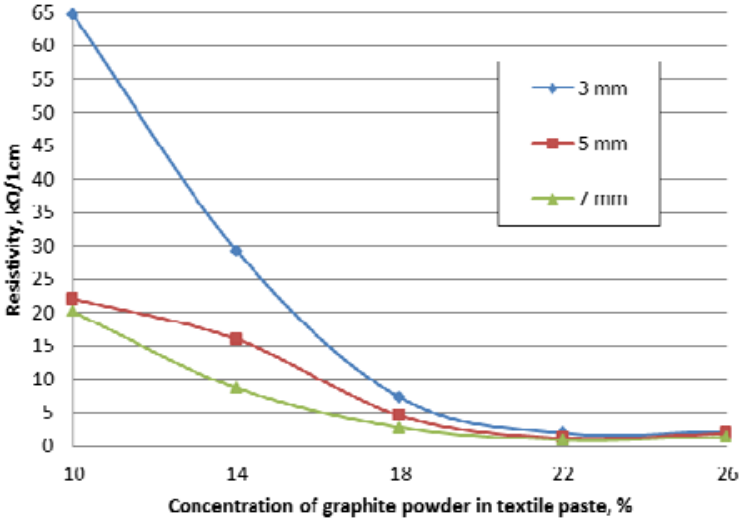

Fig. 4 Dependence of coating resistivity on graphite concentration and thickness of traces on cotton sateen weave fabric

\section{B. Reaction of Sensor on Humidity}

The graph in Figure 5 shows that traces with graphite concentration of $10 \%$ and $22 \%$ have one of the best characteristics, because they reach $1,6 \mathrm{~V}$ after 2,5 seconds. The printed traces with graphite concentration of $18 \%$ reach this level after 3,6 seconds, $14 \%$ - after 5,7 seconds. The longest delay was observed for the traces with graphite concentration of $26 \%$, the mentioned level was reached only after 7,4 seconds. It can be explained by the high concentration of graphite, which made the printing paste more viscous and less absorbing into the structure of the fabric. So it takes some time for dilution to absorb into the fabric under printed traces and then to reach the printed area.

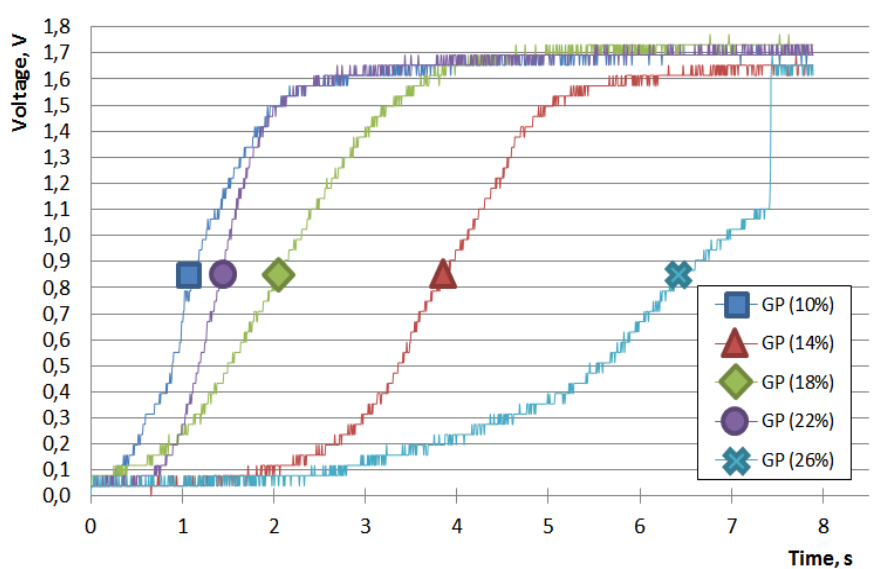

Fig. 5 Reaction on humidity between $5 \mathrm{~mm}$ trace and $7 \mathrm{~mm}$ trace in different concentration of graphite paste (GP)

\section{CONCLUSIONS}

Screen printing electro conductive traces are affected by such factors as: the features of printing paste (viscosity, concentration of graphite, the size of graphite flakes), the size of cells of the screen, the structure of a textile material.

The bigger concentration of graphite powder in printing paste, the less electrical resistance of printed samples was observed, using definite printing stuff and materials. To avoid cracks in printings, thereby improving conductivity, a cohesive substance in the paste must be used.

The traces with graphite concentration of $22 \%$ are the most suitable ones for humidity sensor, because of their low resistance and good conductivity.

\section{REFERENCES}

1. Al-Saleh, M. H. Nanostructured Conductive Polymeric Materials. Ottawa: Library and Archive, 2009. ISBN: 978-0-494-55839-3.

2. Chemicool [online]. [viewed 5 April 2012]. Available from: http://www.chemicool.com/elements/carbon.html

3. Creating conductive solutions [Online]. Creative Materials. [viewed 10 April, 2012]. Available from: http://server.creativematerials.com/datasheets/DS_101_80.pdf.

4. Dimanta un grafita struktūra [online]. Dabaszin̄ātnes un matemātika. [viewed 4 May 2013]. Available from: http://www.dzm.lu.lv/dbz/IT/D_10/default.aspx@tabid=13\&id=215.htm 1

5. DuPont. [Online]. [viewed 22 March 2012]. Available from: http://www2.dupont.com/MCM/en_US/.

6. Fabrication Methods [online]. Graphene ND. [viewed 5 September 2013]. Available from: http://www.grandproject.eu/index.php?id=fabricationmethods

7. Henkel [online]. [viewed 20 March 2012]. Available from: http://www.henkelna.com/product-search-

1554.htm?nodeid $=8798048321537$.

8. Karaguzel, B. et al., Flexible, durable printed electrical circuits. Journal of the Textile Institute. 2009, 100:1, 1-9, North Carolina State University. http://dx.doi.org/10.1080/00405000802390147

9. Karaguzel, B. Printing Conductive Inks on Nonwovens: Challenges and Opportunities. ProQuest Information and Learning Company, 2006.

10. Kazani, I. et al. Electrical Conductive Textiles Obtained by Screen Printing. FIBRES \& TEXTILES in Eastern Europe. 2012, 20, 1(90) pp.57-63.

11. Nocturnal enuresis. The management of bedwetting in children and young people [online]. National Institute of Health and Care Excellence, 2009. [viewed 15 June 2013]. Available from: http://www.nice.org.uk/nicemedia/live/13246/51367/51367.pdf

12. Panhius, M., Wu, J., Ashraf, S.A. et. al. Conductive textiles from singlewalled carbon nanotubes. Elsevier B. V., 2007.

13. Parkova I. et al, Analysis and improvement of nocturnal enuresis alarm system. In: Proceedings of 14-th Romanian Textiles and Leather Conference - 2012, Sianaia, Romania, 2012, pp.256. - 264.

14. Pudas, M., Halonen, N., Granat, P., et.al. Gravure Printing of Conductive Particulate Polymer Inks on Flexible Substrates. Elsevier B.V., 2005.

15. Raymond\&Co [online]. [viewed 22 March 2012]. Available from: http://www.raymondnco.com/english/conductive.html\#spec

16. Rius, J., Manich, S., Rodriguez, R. et.al. Electrical Characterization of Conductive Ink Layers on Textile Fabrics: Model and Experimental Results.

17. Rogers, J. A., Baca, A.J., Ahn, J. H., et.al. Semiconductor Wires and Ribbons for High-Performance Flexible Electronics. Angewandthe Chemie. Wiley-VCH, 2008, 47, pp. $5524-5542$.

18. Screen a Print System [online]. Screen a Print. [viewed 7 July 2013]. Available from: http://www.screenaprint.com/screen-a-printsystem.html

19. Sun Chemical [online]. [viewed 20 March 2012]. Available from: http://www.sunchemical.com/products--services/products/printedcircuit-products/conductive

20. TedPella [online]. [viewed 20 March 2012]. Available from: http://www.tedpella.com/semmisc_html/SEMpaint.htm

21. Trinity College Dublin [online]. Conductivity, Theory and Practice. [viewed 29 June 2013]. Available from: http://www.tcd.ie/Biochemistry/courses/js_conductivity.pdf 


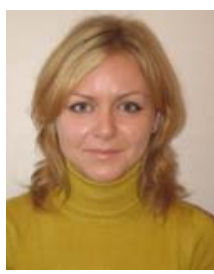

Marianna Grecka, MSc.ing., Doctoral student. She received a Professional Bachelor Degree in Material Technology and Design in 2010 from Riga Technical University and received a Professional Master Degree in Clothing and Textile Technology in 2012 from Riga Technical University. The title of the current thesis is "Projection of Functional Clothing".

Researcher (2011-2012), Institute of Textile Materials Technologies and Design, Riga Technical University.

Project and Textile Materials manager, L.t.d. Develop Baltic.

Field of research: smart textile, integration of electronics in clothing.

Address: Riga Technical University, Institute of Textile Materials Technologies and Design, Azenes Str. 18, Riga, LV-1048, Latvia E-mail: marianna.grecka@rtu.lv

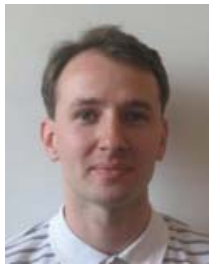

Aleksandrs Valisevskis. Riga Technical University, Institute of Information Technology, Doctoral Degree in Engineering, 2006. Fields of study: Decision-making under uncertainty; fuzzy systems; computer science.

Leading researcher, Institute of Textile Materials Technologies and Design, RTU, Azenes 14, Riga, Latvia. Research interests: wearable electronics; powering of wearable systems; decision-making under uncertainty; fuzzy logic.

The Charles Babbage Award of the University of Latvia in 2001. The Young Scientist Award of the Latvian Academy of Sciences and JSC Aldaris in 2003. The Young Scientist Award of the Latvian Academy of Sciences in 2008.

Address: Riga Technical University, Institute of Textile Materials Technologies and Design, Azenes Str. 18, Riga, LV-1048, Latvia

E-mail:aleksandrs.valisevskis@rtu.lv

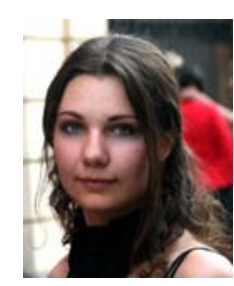

Inese Parkova. Riga Technical University, Institute of Textile Materials Technology and Design, Mg.sc.ing, 2010. Fields of study: optical fibre fabric integration into textile products.

Research Assistant, Institute of Textile Materials Technologies and Design, RTU, Azenes 14, Riga, Latvia. Garment technologist, LLC Solution. Assistant of project leader, Institute of Transport Vehicle Technologies, RTU. Werner von Siemens Excellence Award 2011; Inclusion into RTU Zelta fonds 2010 best student list; Current Doctoral research: electronic systems integration into clothing, innovative textile materials, smart clothing.

Address: Riga Technical University, Institute of Textile Materials Technologies and Design, Azenes Str. 18, Riga, LV-1048, Latvia

E-mail: inese.parkova@rtu.lv

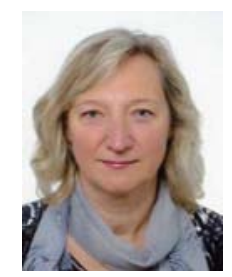

Ausma Vilumsone, Dr.sc.ing., Professor, (1993) at RTU, Institute of Textile Materials Technologies and Design

She is the Head of theInstitute of Textile Materials Technologies and Design, Head of the Department of Clothing and Textile Technologies.

Fields of research: development and optimization of garment design technological process, $\mathrm{CAD} / \mathrm{CAM}$ systems in product design, innovative materials and

technologies.

Address: Riga Technical University, Institute of Textile Materials Technologies and Design, Azenes Str. 18, Riga, LV-1048, Latvia

E-mail: ausma.vilumsone@rtu.lv

Marianna Grecka, Aleksandrs Vališevskis, Inese Parkova, Ausma Vị̣umsone. Sietspieduma tehnikā drukāts enurēzes signālsistēmas sensors Tekstiliju apdruku ar elektrību vadošiem celiniem, shēmām, antenām un sensoriem iespējams izmantot kā alternatīvu elektrību vadošiem tekstila pavedieniem. Apdrukas pastas var saturēt metāliskas, oglekḷa dạ̧iņas un elektrību vadošus polimērus.

Pētījuma mērḳis ir izstrādāt uz auduma drukātu enurēzes signālsistēmas sensoru kā aizvietotāju esošajam, palielinot lietošanas ērtuma līmeni. To var izmantot indivīdi, kuriem konstatēta nakts enurēze jeb nekontrolēta urīna noplūde miega laikā, parasti bērniem vecākiem par 5 gadiem, ko izraisa dažādi fiziologiiski traucējumi. Enurēzes sensors reaǵē uz pirmajiem urīna pilieniem un ar audio signālu pamodina bērnu, kuram ir jācel̦as un jādodas uz tualeti.

Sensora izstrādei tika pielietota sietspieduma apdrukas tehnoloǵija. Kokvilnas satīna audums apdrukāts ar dažāda platuma joslām $(3 \mathrm{~mm}, 5 \mathrm{~mm}, 7 \mathrm{~mm})$, izmantojot caurspīdīgu tekstila apdrukas, kurai dažādās koncentrācijās piejaukts grafìta pulveris.

Pēc drukāto joslu termofiksācijas, izmantojot multimetru, tika noteiktas to vidējās pretestības, izmantojot multimetru. Pieslēdzot paralēlās grafìta joslas pie elektrodiem un pilinot sāls škīidumu, tika reǵistrēta šo joslu reakcija uz mitrumu jeb sprieguma (V) izmainas, kas piefiksētas oscilogrāfu un ilustrētas datorprogrammā Pico Scope 6.

Elektrību vadošas apdrukas kvalitāti ietekmējošie faktori ir: pastas viskozitāte, grafīta koncentrācija un dalinu lielums, drukas sieta šūnu izmērs, apdrukājamās tekstilijas struktūra un absorbcijas spējas. Jo lielāka grafìta koncentrācija pastā, jo mazāka ir drukāto celiṇu pretestība. Lai izvairītos no drukas slāṇa plaisāšanās, ieteicama saistvielas pievienošana pastai. Sensoram atbilstošākā drukas pasta ir ar $22 \%$ grafîta koncentrāciju, jo tai ir zema pretestība un laba vadāmība.

\section{Марианна Грецка, Александр Валишевскис, Инесе Паркова, Аусма Вилюмсоне. Трафаретная печать для сенсора сигнальной системы энуреза}

Нанесение электропроводящих полос, схем, антенн и датчиков методом печати по текстилю может быть использовано как альтернатива электропроводным нитям. Пасты для печати могут содержать частицы металлов, углерода и токопроводящие полимеры.

Целью исследования является разработка напечатанного на ткани сенсора сигнальной системы энуреза, взамен сушествуюших датчиков и более удобного в использовании. Датчик может быть использован индивидами с диагнозом ночной энурез (неконтролируемое выделение мочи во время сна) у детей в возрасте старше 5 лет, вызванный различными физиологическими расстройствами. Сенсор реагирует на первые капли мочи и срабатывает аудио-сигнал в качестве будильника.

Для разработки датчика была использована технология трафаретной печати. Используя полупрозрачную пасту для печати на текстильной основе, которая была смешана с различными концентрациями графитного порошка, на хлопковом атласе были напечатаны полосы различной ширины (3 мм, 5 мм, 7 мм).

После термической фиксации графитных полос, с помощью мультиметра было определено их среднее сопротивление. Подключив электроды к параллельным полосам и капая солевой раствор между полос, была зарегистрирована реакция на влажность, то есть, изменения напряжения (V), которое зафиксировано осциллографом и программой Pico Scope 6.

На качество токопроводящей печати влияют такие факторы как вязкость пасты, конщентрации графита и размера частиц, размер ячейки печатной сетки, структура и абсорбционная способность ткани. Чем выше концентрация графита, тем ниже сопротивление напечатанной дорожки. Чтобы избежать растрескивания слоя печати, рекомендовано добавить в пасту вяжущее вещество. Наиболее подходящая концентрация графитного порошка является $22 \%$, из-за его низкого сопротивления и хорошей проводимости. 